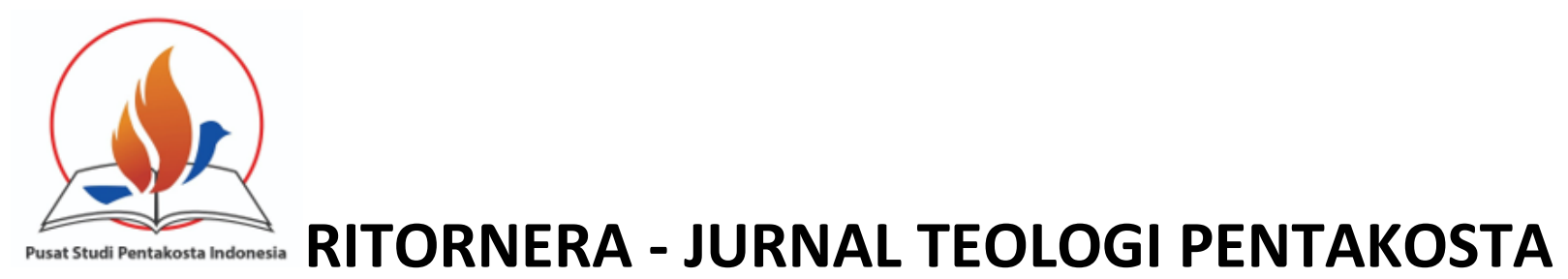

INDONESIA

Vol. 1, No. 2, August 2021

Available at: pspindonesia.org

\title{
Vista Siklus Apostasi Kuasa doa dalam Kitab Hakim-hakim untuk Intensi
}

relevansional

Fati Aro Zega

zegafatiaro@gmail.com

\begin{abstract}
The description of human depravity and apostasy can be seen clearly in the Book of Judges. This book is a historical record and a metaphor for the tendency in every age and every generation to the phenomenon of apostasy. Apostasy occurs not because of not acknowledging the existence of God but believing in something other than God. It turns out that the only thing to learn from history is not to study history. Using a descriptive qualitative method with a literature study approach, it is concluded that the sin of apostasy makes all human achievements in vain. All the results of hard work cannot be enjoyed. Sin takes whatever is gained. It will even bring disaster to humanity, until they repent. However, if they truly repent, seek God, and pray for His mercy, then according to the revelation in the Book of Judges, God will bring relief, healing. The definitive Judge, Jesus Christ, will intervene in anything that humans cannot do. An important principle that appears in the Book of Judges as a biblical truth, "the sin of apostasy produces suffering, prayer and repentance beget prosperity. God plus obedience will produce power, God's grace is greater than all sin.
\end{abstract}

Keywords: Vista Cycle, Prayer, Judges, Relevance.

\begin{abstract}
Abstrak
Gambaran kebejadan dan apostasi manusia itu terlihat dengan jelas di dalam Kitab Hakim-hakim. Kitab ini menjadi catatan sejarah dan metafora tentang tendensi di setiap zaman dan setiap generasi terhadap fenomena apostasi. Apostasi terjadi bukan karena tidak mengakui adanya Tuhan tetapi memercayai sesuatu selain Tuhan. Ternyata satu-satunya yang dipelajari dari sejarah adalah tidak mempelajari sejarah. Mengunakan metode kualitatif deskriptif dengan pendekatan studi literatur didapatkan kesimpulan bahwa dosa kemurtadan membuat semua prestasi manusia sia-sia. Semua hasil kerja keras tidak dapat dinikmati. Dosa merampas apa pun yang diperoleh. Bahkan akan mendatangkan bencana kemanusiaan, sampai mereka bertobat. Tetapi, jika mereka sungguhsungguh bertobat, mencari Tuhan, dan berdoa memohon belas kasihan-Nya, maka sesuai dengan wahyu di Kitab Hakim-hakim, Tuhan akan mendatangkan kelegaan, kesembuhan. Hakim yang definitf, Yesus Krustus, akan turun tangan mengatasi apa pun yang tidak bisa dilakukan manusia. Prinsip penting yang muncul dalam Kitab Hakim-hakim sebagai sebuah kebenaran alkitabiah, "dosa
\end{abstract}


apostasi mengasilkan sengsara, doa dan pertobatan melahirkan kesejahteraan. Stefanus Agus Budi Yanto \& Paulus Kunto Baskoro: Kajian Teologis Konsep Hidup Tekun

Allah di tambah ketaatan akan mengasilkan kuasa, kasih karunia Tuhan lebih besar dari segala dosa.

Kata Kunci: Vista Siklus, Doa, Hakim-hakim, Relevansional.

\section{PENDAHULUAN}

Rasanya benar teori yang disampaikan Heraclietus, panta rhei (panta $\sim$ rei), ${ }^{1}$ segala sesuatu mengalir, selalu berubah. Yang tidak berubah adalah perubahan itu sendiri. Bahkan dunia selalu mengalami goncangan, semakin lama semakin menggegar. Bukan goncangan alami, tetapi goncangan kemanusiaan yang disebabkan oleh gebrakan ilmu pengetahuan yang telah menciptakan disrupsi teknologi, juga disrupsi mindset. Mindset adalah bagaimana manusia berpikir yang ditentukaan oleh setting yang di buat sebelum berpikir dan bertindak. ${ }^{2}$ Sesuatu yang sudah terbentuk, menjadi keyakinan dan pola pikir. Tetapi oleh perubahan yang begitu cepat yang diciptakan teknologi, semua yang dulunya baku kini dibongkar, menuntut mindset yang baru, suatu tuntutan yang bukan alang kepalang "bagi manusia yang hidup pada zaman baru, zaman digital yang serba cepat, mobilitas tinggi, informasi melekat pada diri setiap orang. Termasuk di dalamnya disrupsi keimanan yang diciptakan daya cipta manusia yang melahirkan apostasi.

Bagaimana tidak? Kalau selama ini semua menerima pengertian agama sebagai sebuah konsep yang dipandang menjadi karakteristik dari segala sesuatu yang religius, yaitu konsep supernatural. Bahwa yang Supernatural adalah tatanan hal-ihwal yang berada di luar kemampuan pemahaman manusia, dunia misteri, yang tidak bisa diketahui atau yang tidak bisa ditangkap akal dan dicerap indera, agama menjadi semacam spekulasi terhadap segala sesuatu yang ada di luar sains atau

\footnotetext{
${ }^{1}$ Fatricia O'Grady, Meet the Philosophers of Ancient Greece (Farnham, England: AshgatePublishing Limited, Burlinton: Ashgate Publishing Company, 2005), 64.

${ }^{2}$ Rhenald Kasali, Self Disruption (Jakarta: Mizan Anggota IKAPI, 2018), 305.
} 
akal sehat pada umumnya, ${ }^{3}$ kini dirombak sedemikian rupa. Berikut ini sebuah contoh apostasi spiritualitas, sebagai contoh gerakan perubahan yang menuju kepada apostasi.

Naviri Magazine merilis sebuah artikel yang berjudul "Artificial Intelligent dan Lahirnya Agama Baru yang Menyembah Teknologi.” Ditulis di sana: Selama ini, mengenal agama sebagai sistem kepercayaan yang diyakini ajaran-ajarannya datang dari langit, yang disebut wahyu. Agama memiliki nabi. Kini, seiring perkembangan zaman dan kemajuan teknologi yang semakin canggih, ada agama baru yang tampaknya tidak lagi melewati proses sebagaimana agama-agama sebelumnya. Agama baru yang telah lahir ini tidak melalui mekanisme pewahyuan, memiliki Tuhan yang bisa dilihat, tidak mewajibkan ibadah dalam bentuk ritual tertentu, serta tidak menawarkan surga atau neraka ... Agama baru itu digagas oleh Anthony Levandowski, mantan eksekutif Google, pendiri Otto, juga pernah bekerja untuk Uber. Lewat wawancara dengan Wired, Levandowski membeberkan dasar pendirian agama itu beserta tujuannya. Agama baru itu bertujuan merealisasikan, menerima, dan memuja ketuhanan berdasarkan kecerdasan buatan (AI) lewat pengembangan perangkat keras dan lunak. ${ }^{4}$

Ini bukan kelakar modern atau sikap iseng untuk mencari sensasi. Dengan mendobrak segala keyakina tradisional, Levandowski memberi nama untuk agamanya itu Way Of the Future (WOTF), yang telah diajukan secara resmi pada Mei lalu (2021) ke Internal Revenue Service, Amerika Serikat. Levandowski mengajukan diri sebagai pimpinan agama itu, sekaligus CEO perusahaan. Manusia pintar, teknolog piawai ini, seperti kembali hendak menentang TUHAN yang sejati, sebagaimana di zaman yang ditulis dalam Kejadian 6:5 "bahwa kejahatan manusia besar di bumi dan bahwa segala kecenderungan hatinya selalu membuahkan kejahatan semata-mata. Mungkin bukan kejahatan dalam arti praktis, tetapi secara spiritual. Fenomena ini sepertinya sesuai dengan nubuat dalam Kejadian 11:6 “apapun juga yang mereka rencanakan, tidak ada yang tidak akan dapat terlaksana.” Dan Rasul

\footnotetext{
2008), 49.

${ }^{3}$ Emile Durkheim and Joseph Ward Swain, The Elementary Forms of the Religious Life (Courier Corporation,

${ }^{4}$ Naviri.Org, “Asal Usul Artificial Intelligence (Kecerdasan Buatan),” NAVIRI MAGAZINE, 2018, https://www.naviri.org/2018/02/asal-usul-artificial-intelligence.html.
} 
Paulus juga telah melihat imajinasi agama baru ini, dalam Roma 1:21-23. Lebih jauh tentang agama ini, sosok tuhan dalam WOTF berbeda dengan Tuhan yang di kenal. "Bukan Tuhan penyebab petir atau badai," Levandowski mendefinisikan tuhan sebagai kecerdasan buatan yang memiliki kekuatan dan kecerdasan lebih dari manusia. "Jika ada sesuatu yang miliaran kali lebih cerdas dari manusia, maka bagaimana manusia harus menyebutnya?" katanya. Ajaran utama WOTF adalah pentingnya melakukan penelitian untuk menciptakan kecerdasan buatan. ${ }^{5}$

Seperti dalam penyebaran agama, Levandowski meminta siapa pun yang percaya dan setuju dengan idenya untuk menyebarkan agama ini. Fenomena saat ini, di mana terhubung lewat ponsel, sensor, dan pusat data, menunjukkan bahwa kecerdasan buatan hadir di tengah-tengah manusia. Kecerdasan buatan menjadi tahu apa pun yang di katakan dan lakukan lewat perangkat. Sebagai yang mahatahu, Levandowski mengatakan, kecerdasan buatan bisa disebut tuhan. ${ }^{6}$ Sekarang, tuhan berupa kecerdasan buatan itu, masih dikendalikan manusia, tetapi tidak di masa depan. Dia mengakui idenya tersebut kontrovesial, radikal, dan menyeramkan. Dia siap dengan konsekuensi bahwa tak semua orang menerima gagasannya. ${ }^{7}$ Berdasarkan fenomena di atas, penulis merasa tertarik untuk membahas tema tentang kemurtadan manusia versus kuasa doa, untuk menekankan kembali bahwa ada kalanya Tuhan membiarkan "setiap orang berbuat apa yang benar menurut pandangannya sendiri." (Hakim 17:6) Tetapi bencana kemanusiaan akan Tuhan nyatakan untuk menegakkan kekudusannya agar manusia bertobat dan berdoa memohon pengampunan Tuhan. Melalui survei dan tinjauan relevansionalnya atas Kitab Hakim-hakim, penulis memberi judul artikel ini Vista Siklus apostasi dan kuasa doa dalam kitab Hakim-hakim untuk intensi relevansional.

\section{METODE}

\footnotetext{
${ }^{5}$ Naviri.Org.

${ }^{6}$ Naviri.Org.

${ }^{7}$ Naviri.Org.
} 
Penelitian dalam paper ini menggunakan metode kualitatif deskriptif. ${ }^{8}$ Dimana Alkitab sebagai sumber utama. Penulis juga menggunakan sumber-sumber acuan yang dapat melengkapi penelitian ini yang masih dianggap menjadi sumber penunjang. Penulis menggunakan beberapa sumber sekunder yang membahas tentang Vista Siklus Apostasi Kuasa doa dalam Kitab Hakim-hakim Untuk Intensi relevansional. Setiap pernyatan terhadap topis tersebut ditelusuri dengan literatur pustaka buku-buku terbaru dan terbitan jurnal untuk menambah penelitian pustaka ini. Dari makna literal maupun makna kontekstual, maka dapat disusun secara deskritif dalam kaitan terhadap kuasa doa.

\section{PEMBAHASAN}

Alkitab dalam keadaan apa adanya adalah catatan sejarah, sekalipun mungkin bukan sejarah pada umumnya. Dengan jujur mencatat peristiwa-peristiwa dan wahyu-wahyu yang tetap relevan dan berkuasa. "Alkitab adalah bukti-bukti iman Kristen.” Mencatat kebenaran-kebenaran dari "faktafakta yang kognitif dan informatif. ${ }^{9}$ Salah satu bukti kejujuran Alkitab dalam mencatat sejarah iman ialah mendeskripsikan apa adanya perilaku orang-orang alkitabiah. Di antara berbagai kisah dan sejarah yang mencatat perilaku umat Tuhan di Perjanjian Lama ialah Kitab Hakim-hakim. Kitab ini menekankan ketidaksetiaan Israel. Khususnya, ketidaktaatan pada perintah Allah untuk membinasakan bangsa Kanaan. Ketidaktaatan ini merupakan kemurtadan rohani, sebab, bukannya tetap setia kepada Tuhan dan beribadah hanya kepada Dia seperti perintah-Nya, sebaliknya, mereka bersikap toleran, lalu mulai mengagumi dan akhirnya menyembah dewa-dewa bangsa Kanaan. ${ }^{10}$ Mereka menyembah ilah-ilah yang bukan Tuhan, di samping Tuhan.

\footnotetext{
8 “Sonny Eli Zaluchu, 'Strategi Penelitian Kualitatif Dan Kuantitatif Di Dalam Penelitian Agama,' Evangelikal: Jurnal Teologi Injili Dan Pembinaan Warga Jemaat 4, No. 1 (2020): 28-38, Https://Doi.Org/10.46445/Ejti.V4i1.167," n.d.

${ }^{9}$ Josh McDowell, Apologetika, Bukti Yang Meneguhkan Kebenaran Alkitab, Volume 1. (Malang: Gandum Mas, 2007), 21.

${ }^{10}$ Thomas L. Constable, "Teologi Kitab-Kitab Yosua, Hakum-Hakim Dan Rut," in A Biblical Theology of the Old Testament, Teologi Alkitabiah Perjanjian Lama, Roy B. Zuc (Malang: Gandum Mas, 2015), 200.
} 
Setiap pelanggaran pasti mendapat penalti. Dikatakan oleh Constable, kemurtadan rohani menghasilkan buah-buah kepahitan dalam budaya Isarel. Secara politis Israel sudah mulai hancur, terjadi saling berselisih di antara suku. Kesatuan bangsa memburuk, kekacauan sosial dan pengabaian hukum meningkat. Orang tidak merasa aman lagi berpergian ke tempat umum. Mereka menggunakan kekerasan untuk memperbaiki kesalahan, tindakan-tindakan tidak bermoral meningkat. ${ }^{11}$ Bahkan "ketidakadilan merupakan hasil tambahan dari kemurtadan Israel. ${ }^{12}$ Itulah citra yang ditampilkan Kitab Hakim-hakim atas umat Tuhan. Namun, kendatipun keboborokan moral dan kemurtadan dibicarakan dengan terbuka, pada sisi lain juga menyampaikan pesan yang sangat penting. Kitab ini "menekankan kasih karunia Allah yang panjang sabar tersedia menghadapi kemurtadan dan ketidakadilan yang merajalela dan terus menerus di antara umat-Nya.

Kegagalan umat itu untuk mematuhi perjanjian dihadapi dengan kesetiaan perjanjian dari Tuhan. ${ }^{13}$ Ketika umat-Nya bertobat dan berdoa, Tuhan tidak tega membiarkan mereka merana, dan segera menjawab doa mereka dengan memberikan seorang penolong dalam setiap pergulatan, khususnya dalam enam episode utama yang diceritakan Buku ini.

\section{Deskripsi Survei Kitab Hakim-hakim}

Kitab Hakim-hakim adalah dokumen alkitabiah yang penting untuk mengenal konteks awal kebangsaan Israel sebelum terbentuknya sebuah negara. Kitab ini mempresentasikan kehidupan, tingkah laku bangsa dan para pemimpin Israel setelah berakhir periode penaklukan atas Kanaan. Juga memberikan gambaran mengenai hubungan antara kepemimpinan Yosua dan para tetua yang hidup sezaman sampai dengan Saul, Daud dan raja-raja Israel lainnya. Melalui masa hakim-hakim ini Israel lambat laun belajar untuk menjadi suatu bangsa, bukan lagi sebagai dua belas suku yang berdiri

\footnotetext{
11 Thomas L. Constable, 200-201.

12 Andrew E. Hill \& John H. Walton, Survei Perjanjian Lama, 3rd ed. (Gandung Mas, 2019), 282.

${ }^{13}$ Andrew E. Hill \& John H. Walton, 283.
} 
sendiri-sendiri. ${ }^{14}$ Dalam bahasa Ibrani nama Kitab ini syofetim, atau kritai dalam bahasa Yunani, dan Judicum dalam bahasa Latin. Nama ini merujuk kepada pemimpin karismatik Israel selama periode setelah Yosua sampai Samuel. ${ }^{15}$

Penulis kitab anonim, kemungkinan oleh Samuel, seperti dipercayai oleh tradisi Yahudi dalam Talmud. Yang jelas, ditulis oleh seorang yang sangat familiar dengan sitz im laben Israel waktu itu. Mungkin oleh seorang penyunting yang mengumpulkan catatan-catatan masa itu dan lama sesudahnya baru diterbitkan. Tiga kali disebutkan bahwa "pada masa itu Israel tidak mempunya raja" $(17: 6 ; 18: 1 ; 21: 25)$, yang mengisyaratkan kitab itu diterbitkan beberapa waktu sesudah kerajaan dibentuk. Berbagai kisah pranasional Israel yang tertera menggambarkan peta perjalanan sejarah, antara okupasi Kanaan dan berdirinya monarki. Kisah-kisah tersebut mengenai kebobrokan rohani disanding dengan tindakan-tindakan gagah berani yang dilakukan oleh para pahlawan bangsa yang lazim disebut hakim atau shâphaț (שפט), yang arti harfiahnya to judge, govern, vindicate, punish, ${ }^{16}$ (menghakimi, memerintah, membersihkan, menghukum), yang tugasnya menyelamatkan (ישעי yasha) atau membebaskan dari penindasan bangsa-bangsa lain (Hakim 2:16). Gelar "hakim" dalam bahasa Ibrani mengadung arti seorang yang berperan untuk membawa ke dalam hubungan benar dengan. Para hakim memiliki tiga fungsi, yaitu pemimpin militer, pemerintahan, dan penyelesai perselisihan. ${ }^{17}$

\section{Kerangka Waktu Kitab Hakim-hakim}

Sekalipun penulis kitab ini tidak jelas, namun menunjukkan suatu kerangka waktu yang dapat ditelusuri berdasarkan data-data berikut. Penulisan terjadi setelah tabut perjanjian dipindahkan dari Silo, pada masa Eli dan Samuel (Hakim 18:31; 20:27; bd. 1Sam 4:3-11). Penulis sering menyebut

\footnotetext{
14 John Balchin et al., "Intisari Alkitab Perjanjian Lama,” Jakarta: Persekutuan, 2008, 55.

${ }^{15}$ Rick Meyers, "E-Sword” (Franklin, TN. USA, 2020).

${ }^{16}$ Meyers.

${ }^{17}$ Leslie Thomas Holdcroft, Kitab-Kitab Sejarah (Malang: Gandum Mas, 2018), 31.
} 
masa hakim-hakim sebagai "zaman itu tidak ada raja" (17:6; 18:1; 19:1; 21:25), yang memberi kesan bahwa kerajaan Israel sudah berdiri ketika kitab ini ditulis. Yerusalem belum direbut dari suku Yebus ( Hakim 1:21; bandingkan. 2Sam 5:7).

Ketiga informasi tersebut menengarai bahwa kitab ini diselesaikan antara sesudah Raja Saul naik tahta (sekitar tahun 1050 SM), tetapi sebelum Raja Daud menaklukkan Yerusalem (sekitar 1000 SM). Tetapi yang pasti, kitab ini mencatat dan menilai masa para hakim dari segi perjanjian (mis. 2:1-5). Musa sudah menubuatkan bahwa penindasan oleh bangsa-bangsa asing akan menimpa bangsa Israel sebagai salah satu kutukan Allah jikalau mereka menyimpang dari perjanjian (U1.28:25,33,48). Kitab Hakim-Hakim menggarisbawahi nubuat tersebut. ${ }^{18}$

Sesuai namanya, Kitab ini memberikan laporan tentang kehidupan, tindakan, dan jabatan hakim. Tuhan masih Raja di Israel, pemerintah adalah teokrasi, dan hakim adalah wakil-Nya. Jabatan mereka tidak diwariskan, mereka hanya dibangkitkan pada kesempatan-kesempatan luar biasa untuk menjadi alat di tangan Tuhan dalam membebaskan Israel dari tangan musuh ketika mereka tertindas, tertekan, atau ditawan. Tugas mereka melindungi hak dan kebebasan, memimpin pasukan melawan musuh, memutuskan perselisihan, mengadili tuntutan hukum, dan menegakkan keadilan. Kitab ini berisi kisah semua hakim kecuali dua yang terakhir, Eli dan Samuel, yang disebutkan dalam 1 Samuel. Buku ini dimulai dengan kompromi dan berakhir dengan anarki dan kebingungan. Kitab Hakim-hakim adalah catatan tentang Israel yang meninggalkan Allah (2:13) dan tentang Dia yang meninggalkan mereka karena ketidaktaatan $(2: 23) .{ }^{19}$

Pada Kitab ini diperlihatkan disloyalitas yang terus menerus lebih parah. Mereka terlibat dalam praktik keagamaan kafir yang dilakukan semakin lama semakin sesat dan menjauh dari Allah. Karena itu Allah membiarkan mereka mengalami penindasan yang berat sampai sadar atas

\footnotetext{
${ }^{18}$ Lembaga Alkitab Indonesia, Alkitab Penuntun (Malang: Gandum Mas, 1998), 370.

${ }^{19}$ Bobert T. Boyd, World's Bible Handbook (Grand Rapid: World Publishing, 1996), 128.
} 
ketidaksetiaan itu dan bertobat. Setelah mengalami hajaran yang berat, mereka dengan rendah hati lalu memohon pertolongan Tuhan melalui pertobatan yang sungguh-sungguh. Yahweh kemudian membangkitkan seorang hakim yang tampil memimpin gerakan pembebasan dan pemulihan. Kitab Hakim-hakim dipartisi menjadi 21 pasal, 618 ayat, ${ }^{20}$ Bagian pertama (1:1-3:6), mencatat kegagalan Israel untuk menyelesaikan sepenuhnya penaklukan negeri itu dan kemerosotan mereka setelah kematian Yosua. ${ }^{21}$ Juga terjadinya kawin campur dan kompromistis ritual. Kedua (3:7-16:31), bagian utama kitab, mencatat enam contoh dari pengalaman Israel yang terulang mencakup siklus kemurtadan, penindasan oleh bangsa asing, perbudakan, lalu berseru kepada Allah di tengah kesusahan, dan pembebasan oleh Allah melalui para pemimpin yang diurapi Roh-Nya. Ketiga (17:121:25), menutup kitab ini dengan kisah-kisah yang hidup dari zaman hakim-hakim, yang menggambarkan betapa dalamnya kerusakan moral dan sosial yang diakibatkan kemurtadan rohani Israel. Kitab ini mengingatkan kita bahwa "satu-satunya pelajaran yang kita tarik dari sejarah ialah bahwa kita tidak belajar dari sejarah. ${ }^{22}$

Kitab Hakim-hakim dapat dilihat sebagai suatu lingkaran dosa, atau vicious circle. Dimulai, pertama, rakyat hidup sejahtera. Tidak ada keperluan khusus. Karena itu, Allah ditinggalkan dan ilah-ilah dari negara tetangga yang kafir mengambil alih kedudukan Allah. Kedua, Allah ditinggalkan, mereka mengikuti keinginan sendiri. Yang dihasilkan adalah Allah membiarkan mereka dan membangkitkan bangsa Moab, Amon, Filistin dan Midian untuk menindas Israel. Ketiga, akibat beratnya penindasan, Israel menyesal dan mengakui kesalahan mereka lalu berbalik kepada Allah. Istimewanya, setiap kali mereka berseru, Allah selalu bersedia mengampuni mereka. Keempat, mereka doa kepada Tuhan, maka Tuhan mengutus seorang hakim untuk pembebasan. Allahlah yang menyelamatkan melalui hakim itu. Setelah itu, kelima, rakyat kembali hidup sejahtera... dan

\footnotetext{
${ }^{20}$ Boyd, 128.

${ }^{21}$ Indonesia, Alkitab Penuntun, 370.

${ }^{22}$ Indonesia, 370.
} 
lingkaran dosa berulang kembali. ${ }^{23}$ Pada bagian apendiks, pasal $19-21$, dikisahkan kengerian akibat hancurnya religiositas dan moralitas karena nihilnya peran seorang pemimpin definitif. Bagian ini merupakan sebuah episode dalam sejarah Benyamin. Sebagai akibat dari kekejian yang dilakukan oleh orang Benyamin di Gibea, nyaris satu suku Israel dimusnahkan, karena para tetua orang Israel merekomendasikan cara untuk menyelamatkan Benyamin dari nasibnya. ${ }^{24}$ Matthew Henry mengatakan, tiga bab yang tersisa dari buku ini berisi kisah yang paling tragis tentang kejahatan orang-orang Gibea yang dilindungi oleh suku Benyamin, sehingga suku itu dihukum berat dan hampir seluruhnya dipotong oleh suku-suku lainnya, selain itu penyembahan berhala suku Dan. Hal ini terjadi karena pada saat itu tidak ada raja, tidak ada hakim, di Israel ( Hak 19:1; 21:25). ${ }^{25}$

\section{Tujuan dan Pesan Kitab Hakim-Hakim}

Narasi yang dirangkum oleh Buku ketujuh dari Alkitab Ibrani ini mengandung beberapa tujuan. Dari aspek historis, memberikan catatan utama sejarah Israel di Tanah Perjanjian sejak kematian Yosua hingga masa Samuel. Dari segi teologis, mengungkapkan kemerosotan rohani dan moral sukusuku Israel setelah menetap di negeri itu, serta menunjukkan dengan jelas dampak-dampak merugikan yang senantiasa terjadi apabila melupakan perjanjian mereka dengan Allah dan mulai mengikuti berhala dan kebejatan. Inilah Kitab yang mencatat perang saudara pertama yang dialami Israel. ${ }^{26}$ Kitab Yosua dan Hakim-hakim mirip dua sisi berlawanan dari satu mata uang. Sisi pertama, Kitab Yosua adalah wahyu yang positif, sedangkan sisi kedua, Kitab Hakim-hakim bersifat negatif. Kitab Yosua menunjukkan bahwa kemenangan, keberhasilan dan kemajuan terjadi karena umat Allah secara konsisten percaya dan taat kepada-Nya. Kitab Hakim-hakim memperlihatkan kekalahan,

\footnotetext{
${ }^{23}$ Balchin et al., "Intisari Alkitab Perjanjian Lama," 55-56.

${ }^{24}$ Meyers, "E-Sword."

${ }^{25}$ Matthew Henry, Tafsiran Matthew Henry. Kitab Hakim-hakim (Surabaya: Momentum, 2019).

${ }^{26}$ Alkitab Hidup Berkelimpahan Life Application Study Bible (Malang: Gandum Mas, 2016), 450.
} 
kegagalan dan langkah mundur karena umat Allah tidak berserah dan taat kepada Dia. Sementara Kitab Yosua menyatakan kesetiaan Allah dalam memberi Negeri dan Tanah Perjanjian, Hakim-hakim menekankan ketidaksetiaaan Israel dalam menaklukkan negeri itu. Tetapi, kalau Yosua menyoroti kebencian Allah terhadap dosa, maka Hakim-hakim memperlihatkan panjang sabar Allah terhadap orang berdosa. ${ }^{27}$

Penekanan utama Hakim-hakim ialah ketidaksetiaan Israel, dan sebaliknya, panjang sabar dan anugerah Allah terhadap orang-orang berdosa. ${ }^{28}$ Pesan lain yang dapat ditarik dari pengajaran kitab ini, pertama, untuk menunjukkan akibat fatal ketidaktaatan kepada Allah. Kedua, seorang pemimpin atau hakim yang benar akan membawa rakyatnya kepada Allah, pemulihan hubungan kepada Tuhan melalui prosesi penyesalan dan pertobatan. Ketiga, sekalipun ada 12 hakim yang memerintah secara legal, tetapi mereka hanyalah mandataris, sedangkan hakim yang sejati adalah Yahweh, seperti disebutkan oleh Yefta, "Tuhan, Hakim" (11:27). Para hakim menerima panggilan ilahi untuk melaksanakan tugas suci, tetapi mereka menyadari bahwa mereka dipilih dan berada di bawah pimpinan kuasa ilahi, dan bukan semata-mata pilihan manusia. ${ }^{29}$ Jumlah hakim dapat dilihat dari beberapa sisi. Berdasarkan pemerintahan, terdapat tiga belas hakim, Debora dan Barak dipandang memerintah bersama. Tetapi karena Abimelek adalah seorang perebut kekuasaan, maka pemerintahannya tidak legal seperti hakim lain yang ditetapkan oleh Allah, sehingga hanya dua belas hakim yang sah. ${ }^{30}$ Memang Eli adalah salah seorang hakim Israel, tetapi tdak dicatat di dalam Kitab ini. Ringkasnya, ada 12 hakim yang sah, tetapi ada 13 pemerintahan seperti hakim dalam Kitab ini, dan di sepanjang sejarah Israel ada 14 hakim alkitabiah.

\footnotetext{
27 Thomas L. Constable, “Teologi Kitab-Kitab Yosua, Hakum-Hakim Dan Rut,” 199.

28 Thomas L. Constable, 199.

${ }^{29}$ Balchin et al., "Intisari Alkitab Perjanjian Lama," 55.

${ }^{30}$ Holdcroft, Kitab-Kitab Sejarah, 29.
} 
Para hakim tersebut, kecuali dalam situasi tertentu, sama sekali tindak bertindak seperti konsep modern tentang tugas seorang hakim. Mereka tidak melaksanakan peradilan. Tugas utama mereka bukan untuk mendengar pengaduan atau membuat keputusan hukum. Mereka adalah para pemimpin militer atau tokoh pembebas, ${ }^{31}$ kecuali mungkin Deborah, yang juga seorang nabiah (Hakim 4:4-5). Kehadiran para hakim tidak lepas dari keadaan-keadaan darurat yang dialami umat Allah. Mereka adalah utusan yang karismatik dan bertindak atas nama Yahweh. Dalam banyak hal, jabatan hakim tidak jauh berbeda dengan jabatan raja. Perbedaan utamanya adalah cara mereka memperoleh jabatannya. ${ }^{32}$ Mereka juga sama dengan fungsi para nabi. Bedanya, para nabi diutus untuk berbicara atas nama Tuhan, maka hakim-hakim itu diutus untuk bertindak atas nama-Nya. Kitab ini juga memperlihatkan tentang kasih setia Allah yang lebih besar daripada kedurhakaan umat. Sejarah para hakim menjadi metafora tentang apostasi dan pentingnya monoloyalitas.

\section{Analisis Teologis}

Periode para hakim diperkirakan mulai dari sekitar tahun 1375 sampai 1050 SM, ketika Israel masih merupakan perserikatan suku-suku. ${ }^{33}$ Struktur politik dan organisasi yang dimiliki Israel pernah dikatakan mirip dengan amfiktioni (amphictyony), yaitu gabungan dari suku-suku atau marga yang bersatu agar dapat meningkatkan dan melindungi sebuah pusat ibadah bersama. ${ }^{34}$ Namun bagi Israel kesatuan suku-suku ini didasarkan atas ikatan etnis dan hubungan khusus dengan Yahwe. ${ }^{35}$ Kitab Hakim-hakim memperlihatkan fluktuatif sikap sakralitas dan profanitas. Setiap kali seorang hakim meninggal, bangsa itu mengalami kemerosotan moral karena mereka melakukan kompromi rohani. ${ }^{36}$ Karena itu Allah membiarkan mereka mengalami penindasan yang berat sampai sadar atas

\footnotetext{
${ }^{31}$ Lasor W.S, Hubbard D.A, and Bush FW, Pengantar Perjanjian Lama 1 Taurat Dan Sejarah (Jakarta: BPK
} Gunung Mulia, 2014), 301.

${ }^{32}$ Andrew E. Hill \& John H. Walton, Survei Perjanjian Lama, 286.

${ }^{33}$ Indonesia, Alkitab Penuntun, 501.

${ }^{34}$ Holdcroft, Kitab-Kitab Sejarah, 31.

${ }^{35}$ Andrew E. Hill \& John H. Walton, Survei Perjanjian Lama, 281.

${ }^{36}$ Alkitab Hidup Berkelimpahan Life Application Study Bible, 451. 
ketidaksetiaan itu, lalu bertobat. Setelah dengan rendah hati berdoa memohon pertolongan Tuhan. Yahweh kemudian membangkitkan para hakim yang tampil memimpin gerakan pembebasan.

Berdasarkan sketsa narasinya, Hakim-hakim merepresentasikan apostasi dan kuasa doa dengan mengekspos suatu sirkuit dosa, karena gagal menunjukkan monoloyalitasnya kepada Allah. Berikut ini enam siklus pemberontakan dan penyelamatan oleh Allah. Siklus pertama, penyerbuan Kusyan Risytaim yang menindas Israel selama delapan tahun (3:7-11), yang berasal dari Mesopotamia. Tetapi ketika 'berserulah orang Israel kepada Tuhan, maka Tuhan membangkitkan seorang penyelamat, yaitu Otniel, anak Kenas, adik Kaleb'. Kedamaian menyusul kemudian selama 40 tahun. Siklus kedua, karena apostasi kembali terjadi, Israel ditindasan oleh Eglon (Hak 3:12-31), raja Moab. 'Lalu orang Israel berseru kepada Tuhan, maka Tuhan membangkitkan bagi mereka penyelamat, yakni Ehud, anak Gera, orang Benyamin' yang memberikan masa damai selama 80 tahun. Siklus ketiga, kelepasan oleh Debora (Hak 4:1 - 5:31), hakim keempat, dibantu Barak, panglima tentaranya. Mereka mengalahkan Yabin, dan Sisera panglimanya. Menyusullah masa damai selama 40 tahun sesudah kemenangan itu. Siklus keempat, kelepasan oleh Gideon yang mengalahkan bangsa Midian dan Amalek yang menindas selama delapan tahun yang sangat berat. Sebelum masuk ke siklus yang kelima, sejarah Israel diwarnai kekacauan yang ditimbulkan oleh Abimelekh, anak Gideon, yang mengangkat dirinya menjadi raja memerintah Israel, sampai diperbaiki oleh hakim yang ke-6 dan ke7, yaitu Tola dan Yair ( Hak 10:1-5). Kelima, penindasan oleh Amon dan Filistin (Hak 10:6 - 16:31), karena kemurtadan yang timbul kemudian setelah zaman Tola dan Yair. Tanah Israel diserahkan Allah serentak, wilayah timur kepada orang Amon dan wilayah barat kepada orang Filistin, selama 18 tahun, sampai Tuhan membangkitkan Yefta yang menjadi hakim kedelapan (Pasal 11). Setelah itu Israel diperintah oleh tiga hakim minor, walaupun Israel Barat tetap berada di bawah kekuasaan 
Filistin, walaupun Simson, hakim ke-12, memerintah selama 20 tahun sebagai hakim yang terakhir dalam Kitab ini. ${ }^{37}$

\section{Vista Siklus Apostasi dan Kuasa Doa Kitab Hakim-hakim}

Rekam-jejak kehidupan Israel di Palestina, menurut Kitab Hakim-hakim, memaparkan kondisikondisi yang memunculkan dua belas hakim berturut-turut, yaitu Otniel, Ehud, Samgar, Debora (bersama Barak), Gideon, Tola, Yair, Yefta, Ebzan, Elon, Abdon, Simson (Hakim 3-16). Enam orang di antaranya, berkaitan dengan apostasi Israel sampai enam kali terhadap Tuhan, dipanggil menjadi pembebas, yaitu Otniel, Ehud, Debora, Gideon, Yefta dan Simson. Indikator kemurtadan itu terlihat dari kata-kata yang sama, bahwa "orang Israel melakukan apa yang jahat di mata Tuhan". Disusul dengan penghukuman dan perhambaan. ${ }^{38}$ Tetapi, ketika mereka bertobat, dalam pengakuan yang hampir sama, “Lalu berserulah orang Israel kepada Tuhan”, Dia mendatangkan anugerah keselamatan dengan mengutus seorang hakim, Berikut ini enam siklus apostasi dan kuasa doa dan relevansinya.

\section{Dijual Kepada Kusyan Risyataim ( Hakim 3:8)}

Kemurtadan ini diawali dengan narasi “Orang Israel melakukan apa yang jahat di mata TUHAN, mereka melupakan Tuhan, Allah mereka, dan beribadah kepada para Baal dan para Asyera" ( Hakim 3:7). Sehingga Tuhan "menjual" mereka. Alat yang digunakan Tuhan untuk menindak mereka adalah Kusyan Risyataim yang didatangkan jauh dari Mesopotamia. The Biblical Illustrator menyoroti, bahwa inilah perbudakan pertama orang Israel sejak mereka keluar dari perbudakan di Mesir. Karena sekarang kemurtadan yang menjijikkan itu ditemukan di Israel, yang menyebabkan langit dan bumi

\footnotetext{
1995), 355.

${ }^{38}$ J. Sidlow Baxter, Menggali Isi Alkitab 1, Kejadian Sampai Ester (Jakarta: Yayasan Komunikasi Bina Kasih, 2004), 275.
}

${ }^{37}$ Tim Penyusun, "Ensiklopedi Alkitab Masa Kini," in JILID I A-L (Yayasan Komunikasi Bina Kasih/OMF, 
malu (Yer. 2:12-13), sehingga mereka dijadikan budak dan pelayan (Hak 3:14). Karena mereka yang tidak mau melayani Tuhan dengan segala kelimpahan dan sukacita, maka mereka harus melayani musuh mereka dalam segala kekurangan, derita dan kesedihan ( Ul 28:47-48). Allah meninggalkan mereka, agar mereka mengetahui nilai pelayanan-Nya dan malang serta sengsaranya di bawah penindasan yang menyengsarakan dan menyedihkan (2Taw 12:8). ${ }^{39}$

Matthew Henry menilai, "Tuhan tidak senang dengan mereka karena itu mencabut pagar keistimewaan mereka, mencabut pagar perlindungan dan membukanya untuk bangsa-bangsa, menjualnya sebagai barang yang disingkirkan, dan yang pertama menyentuh mereka adalah KhushanRishathaim, raja Siria. ${ }^{40}$ Inilah bahaya bagi umat Tuhan yang meningglkan Tuhan dan pelayanan kepada-Nya. Namun ketika mereka bertobat, serta berdoa, maka Tuhan mengutus Otniel. Doa permohonan yang mereka panjatkan membawa kuasa pembebasan ilahi. Joseph Benson berkata, bahwa ketika orang Israel berseru kepada Tuhan, mereka kembali kepada-Nya, mengakui Dia sebagai satu-satunya Pelindung dan Juruselamat mereka, dan berdoa sungguh-sungguh untuk pengampunan, Tuhan membangkitkan seorang penyelamat dan memanggilnya untuk tugas pembebasan mereka. Sejarawan suci tidak memberi penjelasan lebih lanjut tentang perang ini selain bahwa Otniel memperoleh kemenangan atas raja Mesopotamia, dan terciptalah kedamaian yang berlangsung selama empat puluh tahun. ${ }^{41}$

\section{Ditaklukkan Eglon Raja Moab ( Hakim-hakim 3:12-30)}

Generasi baru Israel tidak mau belajar dari sejarah. Mereka "melakukan pula apa yang jahat di mata Tuhan" (3:12). Akibatnya mereka diserang oleh raja Moab, Eglon, yang mengikutsertakan bani Amon dan Amalek, sehingga Israel tunduk 18 tahun lamanya. Generasi itu bukannya lebih cerdas

\footnotetext{
${ }^{39}$ Meyers, "E-Sword."

${ }^{40}$ Matthew Henry's, “Matthew Henry’s Commentary on Whole Bible, Judges 3:12-30” (Rick Meyers All Rights Reserved Worldwide, 2020).

${ }^{41}$ Henry's.
} 
dan belajar dari kesalahan masa lalu, justru mereka kembali melakukan kejahatan. Tuhan jengkel atas kejahatan mereka yang kembali melakukan kemurtadan lagi setelah begitu lama menikmati kebaikan Tuhan pada masa Otniel menghakimi mereka. ${ }^{42}$

Matthew Henry mengatakan bahwa mereka lagi-lagi melanggar perintah-Nya! Rupanya mereka menjadi kebal terhadap semua metode penyembuhan ilahi, sehingga semakin berani melakukan dosadosa karena merasa aman. Tetapi Tuhan membuat mereka tahu bahwa Dia memiliki berbagai tongkat yang dapat digunakan untuk menghukum mereka. Dia menguatkan Eglon, raja Moab melawan mereka. Penindas ini lebih dekat dengan mereka daripada yang pertama, karena itu menjadi lebih menyakitkan. Penghakiman Allah mendekati mereka untuk membawa mereka kepada pertobatan yang sejati. ${ }^{43}$ Sikap Israel ini mengingatkan umat Tuhan untuk hati-hati dan jangan jatuh kepada kesalahan masa lalu. Sekalipun sempat jatuh, cepatlah berbalik sadar dan berseru dalam doa permohonan pertolongan kepada Tuhan. Kitab ini menerangkan, ketika anak-anak Israel berseru kepada Tuhan, maka sekali lagi Tuhan membangkitkan dari kelesuan mereka seorang penyelamat seperti sebelumnya, yaitu Ehud, putra Gera, seorang Benyamin, seorang pria kidal, secara harfiah, "tidak terlatih, canggung, dengan tangan kanan," karena keterampilan yang dimiliki orang lain di tangan kanan ada di tangan kirinya. ${ }^{44}$ Mungkin sang penyelamat bukan seorang yang ideal, tetapi cukup untuk mengatasi masalah kemurtadan Israel.

\section{Diserahkan ke Tangan Yabin dan Sisera Era Deborah-Barak}

\footnotetext{
42 Henry's.

${ }^{43}$ Henry's.

${ }^{44}$ Paul Kretzmann, "Popular Commentary, Judges 3:12-30," (Rick Meyers All Rights Reserved Worldwide,
} 2020). 
Kemurtadan ketiga, dipaparkan sepanjang pasal 4:1-5:31, di era Deborah dan Barak. "Setelah Ehud mati, orang Israel melakukan pula apa yang jahat di mata Tuhan" (Hak 4:1). Frasa "kembali melakukan" secara harfiah berarti "mereka menambahkan, atau terus melakukan, kejahatan. ${ }^{45}$ Frasa ini datang dari kata yâsaph (יסף), yang artinya "to add, increase, do again" (menambah, meningkat, melakukan lagi). Akibatnya, Israel ditindas oleh musuh-musuhnya. Ketika mereka mengalienasi Tuhan, maka Tuhan juga meninggalkan mereka, sehingga mereka kemudian menjadi mangsa yang empuk bagi setiap penindas. Karena mereka menjauhkan diri dari Tuhan seolah-olah Dia bukan Tuan mereka, maka Tuhan menyingkirkan mereka sebagai bukan milik-Nya. Mereka yang melepaskan diri dari pelayanan Allah melepaskan diri dari perlindungan-Nya. Dia menjual mereka ke tangan Yabin yang memerintah di Hazor. Yabin, nama yang sama, atau mungkin masih nenek moyangnya, sebelumnya telah dikalahkan dan dibunuh oleh Yosua dan yang membakar kotanya (Yos 11:1, 10). ${ }^{46}$

Nenek moyang Yabin adalah orang yang pernah ditaklukkan dan diperbudak pada zaman Yosua (Yosua 9). Namun ketika Israel memberontak kepada Allah, bangsa yang dulu ditaklukkan berbalik menjadi penakluk mereka. Tetapi, ketika mereka berseru, maka Tuhan menyelesakan masalah mereka dengan memberikan seorang hakim, Deborah, seorang nabiah, beserta dengan Barak sebagai satu tim. Kuasa doa yang menghasilkan anugerah yang sulit untuk dipahami. Robert Hawker berkata, "Perhatikan bagaimana kasih karunia bekerja. Seruan jiwa, dan seruan itu, ditujukan kepada Tuhan; ini adalah tanda pasti dari anugerah. ${ }^{47}$

\section{Masa Gideon (Hakim-hakim Pasal 6-8)}

Setelah masa damai dan aman selama empat puluh tahun, generasi baru Israel kembali memberontak kepada Allah. Akibat kemurtadan itu, Allah menyerahkan Israel ke dalam kekuasaan

\footnotetext{
${ }^{45}$ Kretzmann.

${ }^{46}$ Henry's, "Matthew Henry's Commentary on Whole Bible, Judges 3:12-30."

47 Robert Hawker, "Poor Man's Commenatary Judges 4:3," (Rick Meyers, e-Sword, the Sword of the LORD with electronic edge, 2020).
} 
yang menyakitkan dari bangsa Midian, sampai Tuhan membangkitkan Gideon menjadi pembebas Israel. Dosa Israel membuat semua kerja keras mereka sia-sia. Semua hasil bumi dan ternak mereka dicuri. Kerja keras merka tidak membuahkan hasil. Dosa yang menyebabkan semua ini. Dosa telah merampas apa yang kita peroleh dengan bekerja keras. Ada banyak pria berprestasi yang kehilangan segalanya dalam hidup karena mereka tidak mau menghentikan dosa mereka." ${ }^{48}$

Ketika mengomentari pasal 6:2-6, lebih lanjut Guzik berkata, "Penindasan orang Midian datang karena dosa Israel. Dosa itu membawa Israel ke dalam kehinaan. Sebelum mereka kembali kepada Tuhan, mereka harus direndahkan, hidup sebagai penghuni gua dan bukan sebagai orang yang beradab dengan baik... Orang Midian tidak terus-menerus menduduki tanah itu, tetapi hanya datang pada saat panen untuk mencuri apa yang ditanam orang Israel, tidak meninggalkan makanan bagi Israel. Kemurtadan membuat Israel dimiskinkan dan dilecehkan sehingga tidak menyisahkan apa pun lagi. Karena itu, kemudian, "anak-anak Israel berseru kepada Tuhan. Setelah musim penghinaan yang panjang, kerja yang sia-sia, kemiskinan, dan didominasi oleh kekuatan yang menindas, Israel akhirnya berseru kepada Tuhan. Doa adalah pilihan terakhir mereka alih-alih sumber daya pertama mereka." ${ }^{49}$ Ini juga pelajaran relevansional. Baxter tegas berkata, "Dalam bidang moral ada perkaraperkara yang senantiasa berhubungan erat, tak dapat dipisah-pisahkan: berdosa dan dilanda sengsara, ... Demikian juga berdoa dan beroleh selamat. Tuhan dapat digerakkan hatinya oleh doa, 50 Doa harus menjadi yang terutama, bukan jalan terakhir. Sekalipun demikian, Tuhan tetap menjawab doa orang yang diserukan dalam tulusan.

Era Hakim Yefta (10:6 - 12:7)

${ }^{48}$ David Guzik's Enduring Word Commentary, Judges 6, The Call of Gideon, in: Rick Meyers (2020), eSword., n.d.

${ }^{49}$ David Guzik's Enduring Word Commentary, Judges 6, The Call of Gideon, in: Rick Meyers (2020), eSword.

${ }^{50}$ Baxter, Menggali Isi Alkitab 1, Kejadian Sampai Ester, 277. 
Penulis Hakim-hakim menarasikan alasan kemurtadan kelima dan akibatnya bagi Israel sehingga ditindas bangsa Flisitin dan Bani Moab, sebagai berikut. Orang Israel itu melakukan pula apa yang jahat di mata TUHAN; mereka beribadah kepada para Baal dan para Asytoret, kepada para allah orang Aram, para allah orang Sidon, para allah orang Moab, para allah bani Amon dan para allah orang Filistin, tetapi TUHAN ditinggalkan mereka dan kepada Dia mereka tidak beribadah. (Hakim 10:6) Israel tertarik pada dewa-dewa karena apa yang diasosiasikan dengan dewa pagan. Baal, dewa cuaca, diasosiasikan dengan kesuksesan finansial. Ashtoret, dewi kesuburan, dikaitkan dengan cinta, seks, dan romansa. Menyembah dewa-dewi dari negara tetangga di sekitar mereka itu adalah masalah menyesuaikan diri dengan budaya populer dengan melakukan apa yang dilakukan orang lain. Penyembahan Israel kepada dewa-dewa tetangga mengingatkan bahwa umat Tuhan sering kali berada dalam bahaya untuk menyembah apa yang disembah dunia. Menjadi intensi kisah ini secara relevansional, umat Tuhan tidak pantas mengikuti cara hidup duniawi.

Dua alasan mengapa orang Israel melacurkan diri kepada dewa-dewa, ilah-ilah palsu dari beberapa negara tetangga ini. Pertama, karena bangsa-bangsa tetangga penyembah dewa-dewa itu begitu makmur dalam kekayaan dan kehormatan, sedangkan diri mereka begitu miskin dan hina. Kedua, karena penyembahan kepada Allah yang benar begitu berat, tetapi takhayul kekafiran yang tidak bermoral itu menyenangkan nafsu daging. ${ }^{51}$ Akibatnya, Tuhan murka dan membangkitkan bangsa Filistin dan bani Moab, selama delapan belas tahun yang berat, menginjak orang Israel dan menindas mereka, sampai Tuhan membangkitkan Yefta sebagai hakim. Guzik menyadarkan, "Untuk pertama kalinya tercatat bahwa Dia menolak untuk menyelamatkan mereka, mengingatkan betapa telah berulang kali Dia membebaskan mereka, namun mereka kembali ke jalan jahat mereka. Dalam pesan murka-Nya jelas terlihat tujuan kasih." Menurut Cundall, rupanya Tuhan sedang menguji ketulusan respon mereka. Tetapi ketika mereka sepenuh hati berserah dan memohon kepada Tuhan Sword.

${ }^{51}$ David Guzik's Enduring Word Commentary, Judges 6, The Call of Gideon, in: Rick Meyers (2020), e- 
(10:15-16), maka akhirnya Tuhan bertindak. Doa yang paling alami bagi kita adalah, "Lakukan padaku apa pun yang menurut-Mu terbaik." Perubahan hati membawa pengaruh yang mengakhiri masa penderitaan Israel dengan cara yang baik. Setelah mereka menyingkirkan dewa-dewa asing dari antara mereka dan melayani Tuhan, Israel akhirnya menemukan bahwa yang terburuk dari melayani Tuhan lebih baik daripada yang terbaik melayani berhala. Tuhan akhirnya tidak bisa tahan lagi melihat penderitaan Israel. Tuhan memandang Israel yang tidak taat dengan belas kasih, bukan kebencian. "Sulit" bagi Tuhan untuk membiarkan Israel tetap berada dalam kesengsaraan, meskipun itu yang terbaik bagi mereka. Seperti orang tua penuh kasih yang sempurna, Tuhan benci melihat Israel menderita, bahkan ketika itu baik untuk mereka. Dia ingin menyelamatkan mereka. ${ }^{52}$

\section{Masa Simson ( Hakim 16:28-31)}

Orang Israel merusak diri mereka sendiri dengan "melakukan pula apa yang jahat di mata Tuhan; sebab itu Tuhan menyerahkan mereka ke dalam tangan orang Filistin empat puluh tahun lamanya." ( Hakim 13:1) Tidak banyak diceritakan tentang kondisi waktu itu, tetapi sepanjang tiga pasal ini membahas pribadi Simson. Dia juga seorang hakim. Namanya datang dari kata shemesh yang artinya matahari. ${ }^{53}$ Karakter Simson dapat dipersamakan seperti suatu campuran antara besi dan tanah liat. Ia menjadi seorang yang kuat bila ia taat kepada Allah dan menjadi lemah bilamana mengikuti keinginan hatinya sendiri yang membawanya kepada hubungan yang tidak kudus dengan gadis-gadis Filistin. Keinginannya untuk mendapatkan kepuasan membawanya kepada suatu kemerosotan moral yang secara tidak sadar telah pula menumpulkan kepekaannya sebagai seorang nazir Allah. ${ }^{54}$

\footnotetext{
${ }^{52}$ David Guzik's Enduring Word Commentary, Judges 6, The Call of Gideon, in: Rick Meyers (2020), eSword.

${ }^{53}$ Sword, "The Combridge Bible for Schools and Colleges, Judges 13:24," (Rick Meyers, e-Sword, the Sword of the LORD with electronic edge, 2020). 2016).

${ }^{54}$ J. Wesley Brill, "Doa-Doa Dalam Perjanjian Lama Dan Perjanjiasan Baru, Doa Simson" (Sabda-OLB,
} 
Simson memiliki kesempatan besar untuk menjadi seorang hakim Israel, tetapi ia ternyata mengalami kegagalan yang menghancurkan. "Hukuman yang diterimanya sama mengerikannya seperti dosanya. Ia kehilangan kekuatan, kelumpuhan rohani, dilanjutkan dengan menyerah pada pencobaan dan kompromi dengan kejahatan. Ia kehilangan kemerdekaannya. Ia kehilangan kedua matanya. Ia menjadi bahan tontonan musuh-musuhnya sementara mereka menyombongkan kemenangan Dagon atas Yehova. ${ }^{55}$ Akhirnya Simson bertobat dan dipulihkan kembali ke dalam persekutuan dengan Allah. Ia berdoa meminta kekuatan dan Allah memberikannya. Ia mati dengan kemenangan atas orang Filistin, yang mati dibunuhnya pada waktu matinya lebih daripada yang dibunuh sewaktu hidupnya. Walaupun Simson mengalami kegagalan, Allah yang merencanakan untuk memakai Simson menolong Israel menghancurkan dominasi orang Filistin (Hak 14:4). Kadang-kadang Allah memakai alat-alat yang kurang baik untuk melaksanakan tugas-Nya tetapi hal itu tidak boleh membuat kita mempunyai gambaran bahwa orang-orang yang dipakai Allah itu selalu demikian. 56

\section{Relevansi Apostasi dan Kuasa Doa Pada Masa Kini}

\section{Vista Apostasi Menurut Kitab Hakim-hakim}

Kemurtadan yang dicitrakan oleh Kitab hakim-hakim adalah suatu karakter yang selalu terulang seperti lingkaran setan. Menurut Biblical Illustrator, alasan-alasan orang Israel terjebak di dalam apostasi memang merupakan masalah yang membingungkan untuk dipecahkan. Mengapa anak-anak dari orang-orang suci seperti Abraham, Ishak, dan Yakub harus menjadi pemberontak yang tidak dapat diperbaiki? Inilah teka-teki yang kita temui di mana-mana dalam sejarah Israel. Alasannya, karena rakyat telah kehilangan pemimpinnya. Apostasi itu adalah bagian dari contoh buruk yang universal. Penyembahan berhala adalah dosa yang sangat mudah menjangkiti generasi baru (yang

$55 \mathrm{~J}$. Wesley Brill.
$56 \mathrm{~J}$. Wesley Brill.

Copyright $(02021$; Ritornera - Jurnal Teologi Pentakosta Indonesia|108 
tidak belajar sejarah), karena kebobrokan hati manusia. ${ }^{57}$ Kata kemurtadan atau apostasi dalam bahasa Ibrani datang dri kata mered (מֶֶר) atau marad, sejajar dengan bahasa Yunani apostasia $(\alpha \pi \circ \sigma \tau \alpha \sigma \iota \alpha)$, yang bermakna memberontak. Dalam Yosua 22:22, pemberontakan itu diwujudkan dengan tingkah laku yang disebut "berubah setia" dari ketaatan kepada Tuhan. Kata murtad dalam bahasa Yunani, dari kata apostasia, yaitu istilah teknis untuk revolusi politik atau penyeberangan seseorang kepada musuh. Dalam Septuaginta kata itu selalu dihubungkan dengan pemberontakan terhadap Allah (Yos 22:22; 2Taw 29:19). Kata apostasia terdapat dua kali dalam Perjanjian Baru. Di Kisah 21:21, diterjemahkan dengan "melepaskan”, selanjutnya merujuk kepada tokoh antikristus (2Tes 2:3), menggambarkan kemurtadan besar yang akan terjadi sebelum manusia durhaka dinyatakan. ${ }^{58}$

Memahami makna apostasi lebih jauh ada baiknya membandingkan istilah itu di dalam PB. Apostasi merupakan bahaya bersinambungan atas gereja, dan Perjanjian Baru berulang-ulang mengingatkannya, seperti di dalam 1 Timotius 4:1-3; 2 Tesalonika 2:3; 2 Petrus 3:17. Sedangkan sifat kemurtadan itu dijelaskan dalam 1 Timotius 4:1 dan Ibrani 3:12, yaitu: 'meninggalkan kepercayaan dan meninggalkan Allah yang hidup'. Apostasi akan bertambah-tambah pada masa-masa pencobaan (Mat 24:9, 10; Luk 8:13), dan digalakkan oleh pengajar-pengajar palsu (Mat 24:11; Gal 2:4) yang membujuk orang-orang percaya meninggalkan Firman yang murni untuk berbalik kepada 'injil lain’ (Gal 1:6-8; 2Tim 4:3-4; 2Pet 2:1-12; Yud 1:4). ${ }^{59}$

Secara relevansional siklus apostasi yang selalu berulang dalam Kitab Hakim-hakim mengjngatkan gereja masa kini bahwa pengingkaran dapat terjadi dalam berbagai manifestasi, baik dalam imajinasi maupun perkataan dan perbuatan. Kecongkakan, keterikatan pada sesuatu yang memperbudak juga dapat menjadi sikap apostasi, terlebih lagi jika sudah mengingkari firman dan

\footnotetext{
57 The Biblical Illustrator. Commentary on Judges 3:12, in: Rick Meyers,

${ }^{58}$ Murtad., "Ensiklopedia Alkitab Masa Kini, Dalam:” (Sabda Online Bible versi Indonesia, 2016).

${ }^{59}$ Murtad.
} 
gereja Tuhan. Salah satu model apostasi kekinian ialah kasus mempertuhankan Artificial Intelligence (AI) oleh agama baru WOTF (Way of The Future) yang didirikan oleh Levandowski. Ini apostasi paling mutakhir dan yang paling mengerikan. Magazine Naviri, dalam artikel yang diturunkan (Insight: Technology), antara lain mengatakan bahwa Kecerdasan buatan adalah salah satu teknologi baru yang terus dikembangkan manusia. Tujuan pengembangan AI tentu saja untuk memudahkan berbagai urusan dan pekerjaan manusia, sehingga proses berbagai kerja bisa dipersingkat sekaligus dipermudah. Namun, di sisi lain, pengembangan AI juga menyimpan bahaya mengerikan. Salah satunya adalah kemungkinan lahirnya diktator abadi yang akan memperbudak umat manusia. Terkait kemungkinan mengerikan tersebut, banyak ilmuwan yang sudah menyatakan kekhawatirannya, termasuk Elon Musk. salah satu pakar teknologi, yang pesimis dengan perkembangan kecerdasan buatan. Apostasi yang paling mengancam kemanusiaan ialah men-tuhan-kan artificial intelligence (AI).

\section{Kuasa Doa}

Kekayaan rohani Kristen tersebar di dalam seluruh Alkitab, sebagai tambang emas yang tidak terbatas. Salah satu kekayaan itu adalah kuasa doa. Doa adalah komunikasi dua arah antara Tuhan, Sang Pencipta, dengan manusia, mahluk ciptaan yang ringkih tetapi beriman kepada Dia. Seperti dikatakan oleh Dyrness, doa bersumber pada hubungan pribadi yang sangat mendalam antara Tuhan dengan umat-Nya dalam kesadaran bahwa kita dapat menghampiri Tuhan. ${ }^{60}$ Doa merupakan salah satu senjata dalam peperangan rohani, kuasa yang membangkitkan kekuatan ilahi, dan yang menghasilkan daya spiritual. Bounds mengatakan: Tidak ada yang lebih penting bagi Tuhan daripada doa dalam berurusan dengan umat manusia. Tetapi juga sangat penting bagi manusia untuk berdoa. Kegagalan untuk berdoa adalah kegagalan di sepanjang garis kehidupan. Itu berarti kegagalan tugas, pelayanan, dan kemajuan spiritual. Tuhan harus menolong manusia dengan doa. Orang yang tidak

${ }^{60}$ William Dyrness, “Tema-Tema Dalam Teologi Perjanjian Lama,” Malang: Gandum Mas, 2004, 146. 
berdoa, oleh karena itu, berarti merampas bantuan Tuhan dan menempatkan Tuhan di tempat di mana Dia tidak dapat membantu manusia. Manusia harus berdoa kepada Tuhan jika ingin kasih Tuhan hadir di dalam dirinya. Iman dan harapan, kesabaran dan semua kekuatan, keindahan, daya vital kesalehan akan layu dan mati dalam kehidupan tanpa doa. ${ }^{61}$ Doa juga memampukan orang-orang percaya untuk berdiri teguh dan hidup didalam Tuhan. ${ }^{62}$

Melalui doa Allah yang transenden itu dapat dijangkau menjadi begitu dekat dan intim melalui iman. Bahkan lebih luas dari sekadar suatu komunikasi. Kata "Doa" mengungkapkan pendekatan terbesar dan terlengkap kepada Tuhan. Kata ini menonjolkan unsur pengabdian. Doa adalah persekutuan dan hubungan dengan Tuhan. Itu kesukaan Tuhan. Itu adalah akses kepada Tuhan. ${ }^{63}$ Menurut Erickson, doa merupakan sebuah bentuk tertentu dari persoalan yang lebih luas, yaitu kaitan antara usaha manusia dengan pemeliharaan Allah. ${ }^{64}$ Doa merupakan pernyataan dari ketergantungan manusia kepada Allah untuk segala sesuatu. Doa mendatangkan kuasa Allah ke dalam kehidupan manusia." ${ }^{65}$ Dalam Alkitab doa adalah kebaktian mencakup segala sikap roh manusia dalam pendekatannya kepada Allah. ${ }^{66}$ Sehingga tidak salah kalau dikatakan banyak orang beriman, “doa menghasilkan mukjizat. Seperti sangat jelas digambarkan di dalam Kitab Hakim-hakim atas orang Israel.

\section{Refleksi Masa Kini}

Setidaknya ada tiga pelajaran penting yang meluap dari kedalam Kitab Hakim.hakim. Pertama, mengajarkan betapa tidak sempurnanya manusia, sekalipun mereka adalah umat pilihan Tuhan.

${ }^{61}$ Edward. M. Bounds, The Weapon of Prayer, Prayer Essential to God, In: (e-Sword Reference Library: Rick Meyers, e-Sword, the Sword of the LORD with electronic edge, 2020).

${ }^{62}$ Yonatan Alex Arifianto and Asih sumiwi Rachmani, "Peran Roh Kudus Dalam Menuntun Orang Percaya Kepada Seluruh Kebenaran Berdasarkan Yohanes 16 : 13,” Jurnal Diegesis 3, no. 1 (2020): 1-12.

${ }^{63}$ Edward. M. Bounds, The Weapon of Prayer, Prayer Essential to God, In:

${ }^{64}$ Millard J Erickson, Teologi Kristen, Volume 1 (Malang, Jawa Timur: Gandum Mas, 2004), 649.

${ }^{65}$ Gultom Joni, “Gembala: Antara Seorang Pelayan Dan Pemimpin,” Preprints 1, no. 1 (2020): 22.

${ }^{66}$ Douglas J.D, Ensiklopedia Alkitab Masa Kini 2 (Jakarta: Yayasan Komunikasi Bina Kasih, 2008), 124. 
Mereka bukannya tidak tahu fakta sejarah. Mereka juga tahu apa yang terjadi apabila mereka meninggalkan Allah. Namun demikian, berulangkali mereka menjalani rute yang sama, yaitu rute pemberontakan. Kitab Hakim-hakim memberikan pelajaran betapa kita memerlukan seorang Penyelamat. Kedua, Hanya rahmat Allah saja yang membuat kita layak. Pelajaran penting dari Hakim-hakim ialah bahwa Allah selalu dan dengan tanpa syarat siap untuk mengampuni dan menyelamatkan orang bertobat (Yes 65:1-3). Ketiga, pentingnya kerendahan hati. Kitab Hakimhakim menyatakan bahwa Allahlah yang menghakimi dan menyelamatkan, bukan manusia. Mungkin saja para pemimpin berasumsi bahwa Allah memerlukan mereka, Padahal mereka hanya alat. Hakimhakim mengajarkan, Allah ditambah dengan ketaatan berarti kuasa! ${ }^{67}$

\section{KESIMPULAN}

Berbagai disrupsi dan perubahan selalu terjadi, termasuk perubahan mindset dan keimanan. Perubahan itu menjadi berbahaya jika penekananya hanya untuk hal-hal yang bersifat pragmatis dan utilitas, men-tuhan-kan kepentingan dan kepuasan sensasional. Itulah yang terjadi pada masa dulu dan kini, yang merupakan pengulangan yang tidak disadari dari kecenderungan imajinasi. Manusia selalu lupa bahwa Tuhan tetap Pengendali atas segala sesuatu dan yang mengontrol seluruh kehidupan. Setiap pelanggaran pasti mendapat penalti. Terlebih pelanggaran yang mengingkari Pencipta dan membuat tuhannya sendiri di samping Tuhan yang sejati.

Kemurtadan Israel diawali dari ketidaksetiaan melaksanakan “misi Kanaan”, membersihkan negeri dari kekafiran bangsa yang mereka gantikan sebagai penghuni dan justru kompromi dalam praktik kekafiran yang harusnya mereka singkirkan. Akibatnya, Allah mencabut hak istimewa, pagar perlindungan mereka dan membukanya untuk bencana yang tidak pernah dipikirkan sebelumnya.

\footnotetext{
${ }^{67}$ Balchin et al., "Intisari Alkitab Perjanjian Lama," 59.
} 
Kemurtadan masa kini ialah menuhankan teknologi dan kecerdasan yang mendehumanisasikan manusia. Akibatnya belum tampak kini, namun diramalkan sangat mengerikan. Dosa kemurtadan membuat semua prestasi manusia sia-sia. Semua hasil kerja keras tidak dapat dinikmati. Dosa merampas apa pun yang diperoleh. Bahkan akan mendatangkan bencana kemanusiaan, sampai mereka bertobat. Tetapi, jika mereka sungguh-sungguh bertobat, mencari Tuhan, dan berdoa memohon belas kasihan-Nya, maka sesuai dengan wahyu di Kitab Hakim-hakim, Tuhan akan mendatangkan kelegaan, kesembuhan. Hakim yang definitf, Yesus Krustus, akan turun tangan mengatasi apa pun yang tidak bisa dilakukan manusia. Prinsip penting yang muncul dalam Kitab Hakim-hakim sebagai sebuah kebenaran alkitabiah, “dosa apostasi mengasilkan sengsara, doa dan pertobatan melahirkan kesejahteraan. Allah di tambah ketaatan akan mengasilkan kuasa, kasih karunia Tuhan lebih besar dari segala dosa.

\section{REFERENSI}

Alkitab Hidup Berkelimpahan Life Application Study Bible. Malang: Gandum Mas, 2016.

Andrew E. Hill \& John H. Walton. Survei Perjanjian Lama. 3rd ed. Gandung Mas, 2019.

Arifianto, Yonatan Alex, and Asih sumiwi Rachmani. "Peran Roh Kudus Dalam Menuntun Orang Percaya Kepada Seluruh Kebenaran Berdasarkan Yohanes 16 : 13.” Jurnal Diegesis 3, no. 1 (2020): 1-12.

Balchin, John, Peter Cotterell, Mary Evans, Gilbert Kirby, Peggy Knight, and Derek Tidball. “Intisari Alkitab Perjanjian Lama.” Jakarta: Persekutuan, 2008.

Baxter, J. Sidlow. Menggali Isi Alkitab 1, Kejadian Sampai Ester. Jakarta: Yayasan Komunikasi Bina Kasih, 2004.

Boyd, Bobert T. World's Bible Handbook. Grand Rapid: World Publishing, 1996. 
David Guzik's Enduring Word Commentary, Judges 6, The Call of Gideon, in: Rick Meyers (2020), e-Sword., n.d.

Douglas J.D. Ensiklopedia Alkitab Masa Kini 2. Jakarta: Yayasan Komunikasi Bina Kasih, 2008.

Durkheim, Emile, and Joseph Ward Swain. The Elementary Forms of the Religious Life. Courier Corporation, 2008.

Dyrness, William. “Tema-Tema Dalam Teologi Perjanjian Lama.” Malang: Gandum Mas, 2004.

Edward. M. Bounds. The Weapon of Prayer, Prayer Essential to God, In: e-Sword Reference Library: Rick Meyers, e-Sword, the Sword of the LORD with electronic edge, 2020.

Erickson, Millard J. Teologi Kristen. Volume 1. Malang, Jawa Timur: Gandum Mas, 2004.

Hawker, Robert. “Poor Man’s Commenatary Judges 4:3,.” Rick Meyers, e-Sword, the Sword of the LORD with electronic edge, 2020.

Henry's, Matthew. “Matthew Henry’s Commentary on Whole Bible, Judges 3:12-30.” Rick Meyers All Rights Reserved Worldwide, 2020.

Henry, Matthew. Tafsiran Matthew Henry. Kitab Keluaran, Imamat. Surabaya: Momentum, 2019.

Holdcroft, Leslie Thomas. Kitab-Kitab Sejarah. Malang: Gandum Mas, 2018.

Indonesia, Lembaga Alkitab. Alkitab Penuntun. Malang: Gandum Mas, 1998.

J. Wesley Brill. “Doa-Doa Dalam Perjanjian Lama Dan Perjanjiasan Baru, Doa Simson.” SabdaOLB, 2016.

Joni, Gultom. “Gembala: Antara Seorang Pelayan Dan Pemimpin.” Preprints 1, no. 1 (2020): 1-30. 
Kasali, Rhenald. Self Disruption. Jakarta: Mizan Anggota IKAPI, 2018.

Kretzmann, Paul. "Popular Commentary, Judges 3:12-30,.” Rick Meyers All Rights Reserved Worldwide, 2020.

McDowell, Josh. Apologetika, Bukti Yang Meneguhkan Kebenaran Alkitab, Volume 1. Malang: Gandum Mas, 2007.

Meyers, Rick. “E-Sword.” Franklin, TN. USA, 2020.

Murtad. “Ensiklopedia Alkitab Masa Kini, Dalam:” Sabda Online Bible versi Indonesia, 2016.

Naviri.Org. “Asal Usul Artificial Intelligence (Kecerdasan Buatan).” NAVIRI MAGAZINE, 2018. https://www.naviri.org/2018/02/asal-usul-artificial-intelligence.html.

O’Grady, Fatricia. Meet the Philosophers of Ancient Greece. Farnham, England: AshgatePublishing Limited, Burlinton: Ashgate Publishing Company, 2005.

“Sonny Eli Zaluchu, 'Strategi Penelitian Kualitatif Dan Kuantitatif Di Dalam Penelitian Agama,' Evangelikal: Jurnal Teologi Injili Dan Pembinaan Warga Jemaat 4, No. 1 (2020): 28-38, Https://Doi.Org/10.46445/Ejti.V4i1.167," n.d.

Sword. "The Combridge Bible for Schools and Colleges, Judges 13:24,." Rick Meyers, e-Sword, the Sword of the LORD with electronic edge, 2020.

Thomas L. Constable. “Teologi Kitab-Kitab Yosua, Hakum-Hakim Dan Rut.” In A Biblical Theology of the Old Testament, Teologi Alkitabiah Perjanjian Lama, Roy B. Zuc. Malang: Gandum Mas, 2015.

Tim Penyusun. “Ensiklopedi Alkitab Masa Kini.” In JILID I A-L, 486. Yayasan Komunikasi Bina Kasih/OMF, 1995. 
W.S, Lasor, Hubbard D.A, and Bush FW. Pengantar Perjanjian Lama 1 Taurat Dan Sejarah. Jakarta: BPK Gunung Mulia, 2014. 